\title{
Developing family support services: A comparison of national reforms and challenges in England, Ireland and Spain.
}

\author{
Harriet Churchill ${ }^{1}$, Sofía Baena ${ }^{2}$, Rosemary Crosse ${ }^{3}$, \\ Lucía Jiménez ${ }^{4}$, and Michelle Millar ${ }^{5}$
}

\begin{abstract}
A major aspect of contemporary European family policies has been substantial developments in 'family and parenting support services' albeit under challenging conditions of austerity in recent years. This article compares and reviews national reforms in family support, child welfare and positive parenting services in England, Ireland and Spain. The analysis critically compares national 'system-wide' reforms and frontline service-based innovations; and situates these within broader national and European policy contexts. The article examines the degrees and ways in which children's and family services reforms across all three countries have been shaped by family support, children's rights and social investment policy orientations; and deliberates national differences in the scope, timing and longevity of reforms. It raises critical issues from rights-based perspectives and reflects on cross-national insights.
\end{abstract}

Keywords: family support; family policy; children's rights; early intervention; social investment; comparative analysis.

1. Lecturer in Social Work, Department of Sociological Studies, University of Sheffield, UK

2. Pre-doctoral researcher, University Loyola Andalucía, Spain

3. Post-doctoral researcher, UNESCO Child and Family Research Centre, National University of Ireland Galway, Ireland

4. Professor of Psychology, Department of Developmental and Educational Psychology, University of Seville, Spain

5. Professor of Political Science and Sociology, UNESCO Child and Family Research Centre, National University of Ireland Galway, Ireland

Address for correspondence: h.churchill@sheffield.ac.uk

Date of first (online) publication: 


\section{Introduction}

The last 20 years have seen European countries substantially reconfigure their portfolio of support and services for children, parents and families. However, the scope and substance of national reforms remain varied and contested (Daly et al, 2015; Jiménez et al, 2019a). In addition, from a comparative studies perspective, some areas (such as family benefits, work-family balance policies; childcare reforms and evidence-based programmes) have been more extensively considered than others (for example, child welfare reforms and family support services). Further, austerity measures in recent years have intensified pressures on provision and spending.

Engaging with this context, this article reviews national strategies and reforms in the areas of 'family and parenting support services' in England, Ireland and Spain. The first section sets out the conceptual and political perspectives informing our comparative review. The second section compares the wider national context related to family support policy and provision in the UK, Ireland and Spain; and introduces their adoption of major child-centred and parental/family-focused reforms in recent decades. The third section extends this analysis with more focal consideration of prominent service-orientated national reforms that traverse child welfare, social services and family support spheres. This section considers substantial 'service-system' and frontline provision innovations; and highlights national differences in the scope, timing and longevity of reforms. Several critical issues from rights-based perspectives are raised and significant short-comings are considered.

\section{Comprehensive frameworks for family support policy and provision}

This section clarifies the conceptions of 'family support' and 'parenting support' which inform our comparative review. These can be 'slippery concepts' (Frost et al, 2015, p.22) as they refer to formal and informal aspects of family-orientated and/or parental-targeted social support and provision; and are infused with assumptions and perspectives related to values, purpose and context. In comparative studies, these complexities are intensified by international cultural, linguistic, policy and provision differences (Boddy et al, 2009). For Frost et al (2015, p.22) these issues 'highlight the importance of unpacking the spaces that family support occupies' - which is an aspect of our review.

Nonetheless, it remains necessary to clarify our key concepts. For comparative reviews, the diversity of policy and provision across countries means broad, reflective approaches to concepts are needed. In their international review of 
'family and parenting support policy and provision', Daly et al (2015) developed the following generic definition of 'family support':

Family support is a set of (service and other) activities oriented to improving family functioning and grounding child-rearing and other familial activities in a system of supportive relationships and resources (both formal and informal). (Daly 2015, p.12)

This definition has four useful features. Firstly, it recognises multiple forms of policies and provisions. These span services (such as family support services; parenting education schemes) and other modalities including cash benefits, housing provision, tax allowances and work-family reconciliation policies (and there are multi-modal approaches). Secondly, the definition recognises family support measures are not only concerned with child-focused initiatives, but also wider family supports such as related to caring for adults. Thirdly, the definition emphasises social welfare traditions whereby importance is placed on promotion of informal and formal social supports for family members and family groups which enhance capacities to fulfil family functions; and promote individual and familial welfare (Canavan et al, 2016). Lastly, reference to 'family functioning' alludes to the normative and regulation features of family policy and family support related to the 'care and control' dynamic (Frost et al, 2015; Featherstone et al, 2018). Informed by human rights and egalitarian standpoints, Daly et al (2015) emphasised the importance of 'anti-poverty, anti-inequality and anti-discrimination measures' as well as recognition that 'family' 'can be defined either by kinship, marriage, adoption or choice' (Daly 2015, p.11).

Daly et al (2015) conceived of 'parenting support' as 'a highly related but also distinct' concept and modality:

Parenting support is a set of (service and other) activities oriented to improving how parents' approach and execute their role as parents and to increasing parents' childrearing resources (including information, knowledge, skills and social support) and competencies. (Daly, 2015, p.12)

This definition recognises parenting support akin to family support also spans service provision and other 'activities' such as economic support. However, parenting support is conceived as more specifically concerned with parental and child-focused support, parenting practices and parent-child relations (Daly, 2015, p. 8).

Although we recognise European literature often employs the terms 'family support' and 'parenting support' more inter-changeably (Boddy et al, 2009), our conceptions of family support and parenting support draw on these perspectives. Our substantive focus, though, is policy and provision targeted at families with children and parents. Further, with our focal interest in 'family and parenting support services', it is also important to note alternative and related terms are employed in European debates to refer to these services or specific categories of 
them, including 'social services' or 'children's services'. This underscores further the differentiated nature of this service domain. Furthermore, family support services often operate across state, market and civil society sectors; and are managed by multiple areas of government (healthcare, education and social services) and multiple levels of government (national and sub-national governments). Bearing in mind these points, for the purpose our comparative review, we broadly define family support services as:

Services and programmes targeted at children and/or young people and their parents and/or their families which variously aim to support families, benefit children and improve the quality of family life and relations.

The discussion above alludes to rights-based frameworks for family support. The UN Convention on the Rights of the Child (UNCRC) states those with parental status have primary duties for children and associated decision-making rights. However, children's rights to welfare, development and equality demand they have 'rights to protection, provision and participation' which places duties on states to uphold children's rights and support parents and families. The European Union's (EU) Recommendation for Investing in Children (European Commission [EC], 2013) stipulates EU member states should ensure children and families have: (1) 'access to adequate resources' via employment and material support; and (2) 'access to affordable quality services' such as healthcare, social services, education and childcare provision. These policies also endorse 'children's rights to participation' in society and decision-making (EC, 2013). In addition, the Council of Europe's (COE) 'Recommendation on policy to support positive parenting' (COE, 2006, p.3) states:

Positive parenting refers to parental behaviour based on the best interests of the child that is nurturing, empowering, non-violent and provides recognition and guidance which involves setting of boundaries to enable the full development of the child.

The COE demands its 47 member states comply with the UNCRC and 'take specific action to eradicate all forms of violence against children including a ban on corporal punishment of children' (p.1). It also calls for public policies that 'create the conditions necessary for positive parenting' (p.2) via 'public transfers and taxation' provision, and 'measures to balance work and family life' (p.2). Key principles for best practice include: universal and targeted support and services; working collaboratively with young people, parents and families; gender equality measures; social campaigns about positive parenting; long-term 'stable' policies and provisions; accessible local services; inter-sectoral cooperation and coordination; and good practice and service evaluation frameworks (p.3).

These European and international frameworks draw on the evolving international research evidence that indicates carefully designed and well-resourced social policies and provisions for children/youth, parents and families can help 
to reduce child poverty, child maltreatment and neglect, health and educational inequalities, domestic abuse and youth offending (OECD, 2009; 2011); counter economic, educational and health inequalities (OECD, 2009: 2011); and increase fertility rates, support mothers' employment and promote gender equality (Adema et al, 2014). There is significant research evidence family and parenting support initiatives can help to promote parenting capabilities, improve family relationships and promote family welfare (Devaney et al, 2013); and reduce social isolation and build social capital (Canavan et al, 2016; Devaney et al, 2013).

\section{The broader context}

This section sets out the national policy backgrounds in England, Ireland and Spain. The review focuses on three prominent contextual features: longer-standing public policy and welfare state similarities and differences pre-2000; common family policy and child welfare developments post-2000 albeit with differences; and approaches to austerity policies.

\section{Long-standing features of family support in the UK/England, Ireland and Spain}

While the UK, Ireland and Spain have several longer-standing social policy similarities, they also have long-standing differences in their government structures, political party politics, welfare state traditions, family policy orientations and social services arrangements.

In terms of government structures, the British 'Westminster model' is often described as distinctive and centralised compared to other welfare states. Major public policy domains (for example, fiscal policies, social security and employment policies) remain highly centralised governed by national policies, departments and legislation. National-level family policy, however, has traditionally been 'implicit' and dispersed with no dedicated family ministry. Several social policy domains, though, such as family law, child welfare and the delivery of public services have been increasingly decentralised to the 'devolved administrations' of Scotland, Wales and Northern Ireland as well as local city-wide or county-wide governments. Further, the UK's first-past-the-post electoral system has facilitated tendencies in the post-war era for single-party majority governments. Moreover, ideological influences in England have reflected its prominent 'two-party politics' dominated by the Labour Party and Conservative Party and their respective orientations towards social democracy, liberalism and conservatism.

Following British colonial rule, the Irish state inherited the Westminster model 
of government and administration. Until recent decades, the Catholic Church and organisations had a powerful influence on Irish society, family life and politics (Fahey and Nixon, 2014; Millar, 2003). Daly and Yeates (2003, p. 88) concluded post-war Irish social policies were shaped by 'Catholicism, colonialism/nationalism and liberalism'. In addition, Ireland's written constitution has influenced political processes and family policies. Ireland's electoral system developed proportional representation which facilitates multi-party politics and often generates coalition governments. Ireland has traditionally operated a relatively centralised approach to public spending, fiscal policy, employment policy and most social policy domains although corporatist policy-making has been significant since the 1980s. Family policy has likewise been significantly centralised although akin to the UK, prior to the 2000s, Ireland did not have a dedicated family ministry. Since 1970, additional regional structures were introduced for health and social services governance.

Contemporary political structures and orientations in Spain emerged with the return to parliamentary democracy in the late 1970s following the Franco dictatorship (1939-1975) and its traditional Catholicism. The last quarter of the 20C saw Spanish society, economy and politics experience 'late but condensed pathways to modernisation' (Ferrera, 2010, p.618). Its electoral system, based on proportionate representation, re-invigorated vibrant party-political politics, with popular leftleaning and social democratic political parties as well as more conservative parties subsequently gaining electoral success. The 1978 Spanish Constitution reflected enduring familialism whereby 'public policy assumes that families and households carry the principal responsibility for social welfare' (Esping-Andersen, 1999, p.51); for example, with articles for 'the social protection of the family', rights to family privacy and family duties for children and kin. However, modern family policies were also evident with endorsement for 'equality between men and women', divorce rights, children's rights and social citizenship (such as rights to education and healthcare). Further, since the return to democracy, the Spanish state has operated federal-like arrangements for regional governments and parliaments, alongside national government/parliament structures and local government structures. Within a framework of national government laws, expenditure and regulations as well as inter-regional government agreements and forums - regional governments have acquired social policy competences, including in the decentralised areas of social services and child welfare. While areas such as public expenditure, social security and employment policies remain dominated by the national government, regional governments have increasingly encompassed revenue-raising and social protection roles. Moreover, sensitivities around overt family policies in the post-Franco context, meant national and regional governments in Spain prior to the 2000s did not tend to operate dedicated family ministries.

These contextual features have influenced welfare state traditions, family policy orientations and social services arrangements. In the mid-1990s, the UK approach reflected an enduring 'strong male breadwinner model' (Lewis, 1992) 
and was characterised as a 'centralised liberal welfare regime' (Esping-Andersen, 1999). The 1950s 'traditional nuclear family' ideal (incorporating heterosexual lifelong marriage, gendered family roles and parental rights in child-rearing matters) continued to influence social rights and social provision reflecting enduring traditional familialism. Nonetheless, prior to the 1990s there was much 'supported familialism' - incorporating universal child benefit, lone parent benefits, paid maternity leave, social housing support, maternal-child health services, community-based social services and the professionalisation of social work. Further, equality campaigns secured abortion/contraception rights, divorce laws and equality legislation - albeit with some exceptions in Northern Ireland. The 'New Right' Conservative governments from 1979 to 1997, however, pursued neo-liberal social policies and traditional conservative family policies leading to reduced social rights, pro-marriage initiatives and 'new public management' (NPM) public service reforms. There were cutbacks in family support and social services alongside new welfare-to-work conditions for state welfare. However, this period also saw important contemporary child welfare measures, including the 1989 Children Act (England and Wales) which placed duties on Local Authorities (LA) to safeguard and promote the welfare of 'children in need' including those 'at risk of significant harm'. Critically though, these measures provided limited rights to family support and were poorly funded. The combination of high referrals and limited provision meant the 'child protection orientation' dominated; and several studies evidenced the lack of support and stigmatising treatment those in need often received (Gilbert, 2012). In addition, related to EU Directives, support for working mothers was enhanced. However, overall in the 1980s and 1990s, the UK witnessed steep increases in child poverty rates and relatively low maternal employment rates for EU-15 standards.

In social policy terms, Ireland has traditionally been regarded as mostly reflecting the 'Corporatist-Conservative' world of Esping-Andersen's classification of welfare regimes (Dukelow and Considine, 2017). However, since the 2000s social policy in Ireland is more akin to the 'neo-liberal' tradition. Until recent decades, the Church and its doctrine on all matters concerning the family and the principle of 'subsidiarity' ensured much traditional familialism (Millar, 2003). In the mid-1990s, dominant concerns of family policy were 'how to assist families with the costs of children' and how to support the traditional family model (Daly and Clavero, 2002, p. 2). Economic support was more generous for large families headed by married couples although economic and political factors (for example, economic problems, social changes, left-wing governments, and EEC membership) led to improved lone parent benefits and maternity leave rights in the 1980s and 1990s (Dukelow and Considine, 2017). However, poverty rates remained high in Ireland and mothers' employment rates low for EU standards.

In relation to health, education and social services, Irish provision developed complex public-private-charity arrangements. Subsidised by the state, Catholic 
and religious organisations developed major service providers roles. Historically, family support services have been 'a very under-developed area of welfare state provision' in Ireland (Daly and Clavero, 2002, p.49) as well as organised, since the 1970 Health Act, on the basis of joint healthcare and social services arrangements. High profile child abuse inquiries and child welfare concerns, however, prompted the 1991 Child Care Act which retains major significance today. Influenced by the Children Act reforms in the UK, this sought to 're-orientate services from reactive child protection to preventative family support approaches' (Cassidy et al, 2016, p.146). However, these reforms 'struggled to maintain adequate resources and deliver effective services in a context of moral panic, resource constraint and increasing awareness of the extent of abuse and harm on children' (Cassidy et al, 2016, p.146).

According to Naldini (2004, p.46) in Spain an enduring legacy of the Franco period until recently was the 'family/kinship solidarity model', whereby 'family and kinship dependencies even amongst adult citizens have been codified in legislation and encouraged and supported by the welfare state'. However, by the mid-1990s, the Spanish welfare state had also developed:

[A]n institutional design organised around, first, a Bismarckian model in pensions, unemployment and labour market policies; second, a Universalistic model in education and health; and, third, a rather limited intervention model in social assistance, social care and family support. (Leon and Pavolini, 2014, p.354)

In respect of social services, national and regional governments had taken steps to move beyond charity-based and residential-based provision towards communitybased services with increased statutory roles (Del Valle et al, 2013). However, limited resources for the development of child welfare and family support services remained a significant problem - resonating with the English and Irish cases (Leon and Pavolini, 2014). Nevertheless, substantial family policy developments were spearheaded by the Spanish Socialist Workers Party (PSOE) government (1982-1996). This introduced modern family policies and laws (divorce rights, same-sex marriage rights and adoption reforms) which placed Spain amongst the highest-ranked European countries in matters of family diversity recognition (Pérez-Caramés, 2014). However, the principle of subsidiarity as well as enduring familialism meant public spending overall for family policies as well as levels of economic supports for families remained substantially below EU averages in terms of cash benefits, childcare, services and tax breaks. Work-family reconciliation policies at this time also lagged behind many European countries, for example, with one of the shortest periods of adequately compensated parental leave for both parents among EU-15 countries (Pérez-Caramés, 2014). 


\section{A revolution in family policy?}

Informed by European and international policy discourses and developments, there have been major new directions in family and childhood policies in the UK, Ireland and Spain in recent decades. Traditional post-war social and family policies have been criticised as outdated, inefficient and unjust; and themes of modernisation, activation, social investment and social prevention have moved centre-stage. The take-up of welfare-to-work schemes, employability schemes, childcare reforms and work-family balance policies have featured highly. Third Way/Centrist welfare state reforms have been promoted which: align citizenship 'rights and responsibilities'; promote 'equality of opportunity' and 'social inclusion' as opposed to 'equality of outcomes'; 'modernise family policies'; extend the role of the state as 'enabler' not merely 'provider'; develop collaborations across policy/service domains and public-private-civil society sectors; and promote evidence-based policies and 'prudent public finances' (Bonoli, 2013). There has been substantial take-up of social investment agendas which aim to 'enhance capacities to flourish' (Hemerijck, 2018, p. 823). These prioritise investment in human and social capital via education and social services. Moreover, social investment strategies promote child-centred and family-focused social prevention policies; adopting public health-inspired early intervention and prevention strategies which enhance 'protections and resilience' against adversities and reduce risks and harms from disadvantages and problems (Churchill, 2011). Further, children's rights advances have promoted more 'child-centred' social and family policies.

In the English context, the New Labour governments (1997-2010) introduced major developments in policy and provision for children, parents and families. Informed by Third Way and social investment goals, these governments sought to: reduce poverty and increase employment; support parents and 'strengthen families'; promote child well-being and prevent social problems; and reform children's services. Greater parental employment and reduced child poverty were closely linked policy goals pursued via welfare-to-work measures, childcare improvements, the Minimum Wage, tax credits and work-family balance initiatives. Family policy underwent modernisation with legislation providing same-sex couples rights to adopt and form civil partnerships. Under favourable economic conditions, these investments and reforms contributed to increases in maternal employment and improvements in child well-being (Churchill, 2011). However, New Labour also adopted punitive tones towards disadvantaged groups deemed failing to benefit from enhanced opportunities which often sharply played out in the child protection system. Social policies further incorporated punitive benefit sanctions and expanded private sector provision in childcare and social services - which increased economic risks and costs for many parents and families. Further, New Labour policies favoured 'dual-earner' rather than 'dual-carer' parental roles. Resistance to ban the corporal punishment of children in families raised children's rights concerns.

New directions in family and children's policies in Ireland developed under 
coalition governments in office since 1997 and alongside greater EU integration as a member of the eurozone. The social partnership-based Anti-Poverty Strategy (1997-2007) and Commission on the Family (1998) promoted social welfare, employment support and family support reforms. These included family benefit increases, the Minimum Wage, welfare-to-work reforms, tax credits, the National Childcare Strategy and maternity leave reforms. The National Action Plan for Social Exclusion (2007-2016) further endorsed greater emphasis on child-centred social investment and active social policies influenced by the Developmental Welfare State report (NESC, 2005) which promoted greater 'synergy between social and economic policies', a 'European social model of high employment' and 'a life-cycle approach' to social investment (pp.11-24). Families with children saw significant improvements in economic support, pre-school and childcare provision, and work-family policies. In addition, family and children services reforms were central to a new emphasis on improving outcomes for children and tackling social exclusion. However, akin to the UK, there were enduring regime tendencies particularly in respect of traditional familialism which was reflected, for example, in limited active labour market policies for mothers and limited rights to maternity leave pay. A more 'paradigmatic shift' was evident in the National Children's Strategy (2000-2010) (Hanafin et al, 2012, p.56). This sought 'an overarching focus on promoting child well-being' across government departments and to promote children's participation in decision-making (Ibid, p.569). After much public debate, in 2015 Ireland introduced a ban on the corporal punishment of children.

Similar to England and Ireland, Spain has adopted significant family policy and family support reforms in recent decades, particularly during the Zapareto administrations and PSOE (Spanish Socialist Workers Party) governments (20042011). In several ways, there were similarities with the Irish case with an explicit EU policy influence, membership of the eurozone, major shifts to 'child-centred' rationales and the launch of National Action Plans in the areas of Social Inclusion and Family Support. Ferrera (2010, p.627) argued that up to the economic crisis, 'the spur of European integration' had prompted 'substantial efforts to recalibrate and modernise the welfare state' with reforms stimulating 'more efficient and equitable labour markets, more sustainable social insurance, and a more effective and inclusive social safety net'. There was positive progression in the support offered to families with new forms of economic support for families with young children, low income families and low earning parents (Elizalde-San Miguel et al, 2019). Further, a ban on corporal punishment of children was introduced in 2007 in Spain and at this time 'very progressive gender equality measures' also began in the area of workfamily policies (Ferrera, 2010). Subsidised pre-school provision was introduced for the over-3s and this was more universal in reach compared to England and Ireland. Moreover, several regional governments went beyond national developments, such as providing additional means-tested economic support for families and investing in social services. 


\section{Challenges and changes under austerity}

In the last decade, the financial crisis severely hit the UK, Irish and Spanish economy. Public spending deficits sharply increased from 2008 to 2010, economic recessions endured until 2013/2014 and detrimental economic effects (such as slow wage growth; restrictions on public sector recruitment) were felt for longer. The UK Conservative-Liberal Democrat Coalition government (2010-2015) adopted major public spending cuts and austerity measures. Ideological shifts also justified these measures. The Conservatives criticised 'Labour's massive expansion of the state' its 'indifference to marriage' and neglect of 'social breakdown in deprived communities' (Conservative Party, 2010, p.35). Cutbacks in provision have since reduced economic support for families and curtailed investment in family support. Welfare-to-work requirements for parents have increased. Further, a stronger disposition towards neo-liberal public service reforms was presented as a shift from 'Big Government' towards 'the Big Society' which has subsequently led to initiatives to reduce the bureaucracy of the welfare state and extend the roles of the private sector, voluntary sector and community self-help in service provision and social welfare (Ibid). However, childhood and family policies since 2010 have also continued to endorse targeted social investments and 'modern family policies'.

The EU/IMF bailout for Ireland during the economic crisis was accompanied by requirements for severe fiscal containment measures. There were major public spending cuts which led to reductions and restrictions in the public sector workforce, and cutbacks in provision such as state welfare and family benefits. However, the centre-left Fine Gael-led Coalitions (2011-2016; 2016-2020) tempered cutbacks and expanded national reforms related to social inclusion, children's services and child well-being. With reference to EU Social Investment policies, the Fine Gael party sought to 'build a fairer society' (Fine Gael Party, p.2011) and 'intensely invest in the early years and early intervention' (Fine Gael Party, 2016). These were key themes in the updated social partnership-based National Recovery/ Social Inclusion Plans and updated National Children's Strategy. In combination with greater child-centred social investment, however, it has also been the last 10 years where Ireland has introduced more extensive and punitive active labour market policies including towards lone mothers reliant on welfare benefits (Millar and Crosse, 2018).

Developments in Spain mirror aspects of both the UK/English and Irish situations and experiences. As Leon and Pavolini (2014, p. 364-365) note, the financial crisis, EU fiscal containment measures and government austerity measures 'brought high unemployment, social unrest and massive social expenditure cuts'. Resonating with the UK Conservative-led governments since 2010, from 2011 to 2018 the Spanish government, headed by the conservative People's Party, implemented 'changes of a more ideological nature that undermined much of the progressive character of legislation introduced by previous governments' (p. 365). Austerity 
measures included non-implementation of reforms introduced under Zapatero (such as progressive paternity leave payments) alongside public expenditure cuts and public sector workforce cuts including in childcare and social services. Reliance on charity-based social services increased (Ibid). However, as discussed below, there were also some important family support innovations during this period, often driven by regional-level and stakeholder initiatives. Further, the socialist PSOE-led Coalition Spanish government since 2018 refocused priorities once more on child-centred and egalitarian endeavours, with for example, implementation of progressive paternity and parental leave reforms in 2018-2019.

\section{Developing family support services in England, Ireland and Spain}

Building on the reviews above, this section examines approaches to, and developments in, family and parenting support services in England, Ireland and Spain. The review compares 'system-wide' reforms and provision developments. While pertinent similarities are considered, so are differences in the timing, approach and sustainability of reforms. Common short-comings and challenges are discussed.

\section{Service-based reforms in England}

The Labour government's Supporting Families strategy (Home Office, 1998, p.32) heralded new directions in family and children's services in England. This strategy promoted 'support and services for all parents' (p.25) as 'authoritative parenting provides children with the best start in life, improves their health, schooling and prospects' and 'reduces the risks of serious problems' (p.6). It also focused on 'improved support for serious problems' (p.6), namely 'youth offending, teenage pregnancy, domestic violence and problems with children's education' (p.40). Measures such as court-sanctioned Parenting Orders and professionally-agreed Parenting Contracts also emphasised parental duties and coercive interventions in response to serious child/youth welfare and behaviour problems.

The Every Child Matters strategy (Chief Secretary to the Treasury, 2003) then introduced major reforms and the Minister for Children, Youth and Families was created. Local government 'children's services' were introduced and assigned new duties to improve five outcomes for children aged 0-19 (economic well-being, being healthy, staying safe, making a positive contribution to society and enjoying and achieving at school). Towards these endeavours Local Authorities (LAs): produced 'Children's services plans' which assessed local needs and audited local services; 
established strategic cross-sector service partnerships; introduced standardised, comprehensive needs-assessments tools; and improved joint-working referral and delivery arrangements. Improved support for parents and families were also central themes (Ibid). LAs developed a four-tier service system organised around: universal services such as health visitors and parenting advice; targeted services for children and families with additional needs and vulnerabilities such as targeted parenting programmes; targeted services for higher need children and families, often referral-based, such as intensive family support services; and, remedial and statutory services providing more extensive specialist, therapeutic services as well as child welfare interventions.

Key provision initiatives included greater investment in positive parenting initiatives (such as family support workers and parenting programmes); expansion of Sure Start programmes (rebranded as Children's Centres providing co-located community-based children's and family services); expansion of the Extended Schools initiative (providing out-of-hours activities, childcare, family learning and parenting support via schools); and developments in home-visiting schemes, support for fathers, family therapy and Family Group Conferences. In addition, from 2006, LAs introduced 'Parenting Support Strategies' and additional central government funding was provided for parenting support coordinators, Parent Support Advisers (PSA) in schools and evidence-based parenting programmes delivery (DfES, 2006).

Then in 2007, the Department of Children, Schools and Families (DCSF) was established and the Children's Plan's (DCSF, 2007) launched. Additional support for parents included increased funding for couple relationships schemes and multi-agency family services. The Children's Plan was followed by the Families at Risk Review (Cabinet Office, 2007) which refocused attention on 'children most at risk' - 'the 2\% of families with children, around 140,000 families in England, that suffered multiple adversities and severe disadvantage'. Reforms emphasised investment in intensive multi-agency services and 'behaviour change' methods (SEFT, 2006). Family Intervention Projects (FIPS) were introduced which provided key workers, structured casework and intensive support for families to achieve 'behaviour change' targets.

Overall these reforms enhanced the capacity and coordination of universal, targeted and specialist services (Tunstill et al, 2008). Independent evaluations reported improved outcomes for children and positive service-user experiences. For example, the evaluation of schools-based Parent Support Advisers (PSA) found 717 PSAs served 1167 schools by 2009 (Lindsay et al, 2009). It found parents valued the personalised and authoritative approach PSAs adopted and their support to better engage with schools and other services (Ibid). Likewise, Sure Start and Children's Centres studies reported improved parenting, improved child development, improved parental well-being and social networks, and improved engagement with services (Melhuish et al, 2008). However, across centres, levels of family engagement 
(for example among fathers), service provision and outcomes for children varied (Melhuish et al, 2008). Some initiatives, such as Family Intervention Projects (FIPS) also received mixed evaluations. The adoption of disciplinary methods and pressurised expectations for 'swift results' were criticised and gaps in specialist/ therapeutic services inhibited effective casework (Churchill, 2011). Other aspects of Labour's approach were also problematic. Access to support (potentially for issues deemed sensitive, private or shameful) was highly bureaucratic (Featherstone et al, 2018). Gender inequality and children's rights perspectives appeared marginal with parenting interventions, for example, overwhelming involving mothers/ women (Churchill, 2011).

The Conservative-led reforms since 2010, however, introduced major cutbacks in services. The Children's Plan has not been updated and the DCSF was disbanded and renamed the 'Department for Education (DfE)', heralding the return to narrowly conceived policy and service domains. Austerity measures particularly impacted on LAs funding, with the National Audit Office (NAO) (2018) reporting central government funding for LAs reduced by 49.1\% from 2010/11 to 2017/18. Analysing LA spending, Kelly et al (2018) found youth services, Children's Centres and family support budgets fell from between 40-70\% from 2010 to 2017.

Eisenstadt and Oppenheim (2020, p.85) argued 'the basic premise' of the Conservative-led coalition's 'social justice' narrative was 'that economic dependence and educational failure, alongside problematic behaviours in adults, drive poor outcomes for children'. This narrative justified austerity measures and re-orientated children's services reforms towards targeted measures for 'the most dysfunctional and disadvantaged families' (Conservative Party, 2010). These included the Troubled Families Programme (TFP) introduced in late 2011 following riots in several English cities. This initiative had much in common with Labour's FIPs scheme and reflected the Coalition emphasis on the failings of parents. Phase 1 of the programme (2010-15) sought to 'turnaround the lives of 120,000 troubled families'. Most LAs adopted FIPs-style 'intensive-intervention' and 'behaviour-change' services. Central government funding involved 'payments-by-results', with families required to meet outcomes in specified time periods. Initially, the TFP sought to reduce receipt of welfare benefits, increase employment, reduced school problems and reduced offending. Then in 2013, Phase 2 was launched attending to additional issues such as domestic violence, child welfare concerns and poor health; and expanding the reach of the TFP to 500,000 families by 2020. The national evaluation of Phase 1 found mixed results (Day et al, 2016). While families valued and benefitted from the support, the evaluation found 'little systematic impact' across the specified outcomes (Day et al, 2016, p. 69). Critical issues were levels of economic stress; limited scope for holistic, long-term casework; and significant gaps in specialist services, such as mental health provision (Featherstone et al, 2018). In addition, there were some reforms in parenting education schemes including the 'Can Parent' programme which provided parenting courses for parents in certain localities. 
However, while the national evaluation highlighted parents reported benefits from completing the programme, it found overall take-up was low (Lindsay et al, 2014).

Further reforms were introduced in social services and child protection. The wide-ranging Munro Review into Child Protection (Munro, 2010) prompted reforms to reduce administrative burdens, improve early intervention and improve multiagency practice - addressing some of the problems discussed above. An emphasis on cost-effectiveness and evidence-based approaches also led to the 'Early Intervention Foundation', 'Children's Social Care Innovation Programme' and the 'What Works for Children's Social Care' centre. These were dedicated to advancing research and practice although their scope tended to be narrowly conceived (for example, the Innovation Programme selectively funded a limited number of initiatives and LAs) and austerity measures have severely reduced funding for these activities elsewhere. Developments since 2010, therefore, have included some worthwhile initiatives but also a return to selectivism, stigmatisation and familialism.

\section{Service-based reforms in Ireland}

Similar to England, there have been extensive children's and family service reforms in Ireland in recent years that have spanned national 'system-wide' changes and frontline service innovations. These have likewise been orientated towards early intervention, joint-up services and evidence-based initiatives. However, in contrast to the English reforms, more incremental reforms developed under the Fianna Failled Coalitions (1997-2011) and more favourable economic conditions; while more comprehensive reforms occurred under the Fine Gael-led Coalitions (2011-2016; 2016-2020) and alongside austerity. In addition, an overt child welfare-orientated family support discourse has been more prominent in Irish debates as well as greater corporatist, collaborative policy-making and greater alignment with EU policies.

Developments in the late 1990 s and early 2000 s responded to the recommendations of the 'Commission on the Family' (1998) which called for improvements in community-based family support, parenting education initiatives, service coordination across sectors and marriage counselling services. It advocated organisational reforms which led to the establishment of the 'Department of Social, Community and Family Affairs' (DSCFA) and 'Department of Health and Children' (DHC). The latter produced new 'National Guidelines for the Protection and Welfare of Children' (DHC, 1999) which 'affirmed the statutory responsibility to provide support services to families of children who may be at risk of abuse or neglect' (Ibid). These guidelines set out wide-ranging roles for family support services in safeguarding and promoting child welfare via services that 'work in a supportive manner with families to reduce risk to children', 'develop existing strengths of parents/carers and children', 'connect families to communities' and 'promote parental competence and confidence' (DHC 1999, p. 60). The DHC 
subsequently established a Steering Group which included several family welfare academics and developed its approach to strength-based, prevention-orientated and evidence-informed family support provision. The Group's 'strategic intent' report set out 10 principles for family support provision (Pinkerton et al, 2004, p.22).

Major national programmes were launched including the Springboard programme which by 2005 funded 22 family support projects delivered by voluntary and/or statutory agencies. Serving families living in disadvantaged areas, these projects provided varied types and levels of family/parenting support adopting multi-agency, prevention approaches. In addition, Family Resource Centres were introduced providing open-access support and services in various communities, with 121 centres in operation by 2019 (www.tusla.ie). From 2001 to 2013, these initiatives then fell under the remit of the national Family Support Agency (FSA) established to spearhead a step-change in service developments. The FSA developed a research and standards programme as well as oversaw provision. There were significant developments in voluntary sector provision, child maltreatment prevention, positive parenting initiatives, peer support schemes (e.g. Community Mothers scheme and Home Start), early intervention programmes, marriage/family counselling, disability services and domestic violence prevention (Rochford et al, 2014). The Prevention and Early Intervention Initiative (PEII) was also launched, jointly funded by government and philanthropy organisations, funding 52 family support services by 2014. Akin to England, investment in services was accompanied by new statutory powers - parental supervision and compensation orders - used to require parental engagement with services where deemed necessary due to serious concerns about child and youth behaviour and welfare.

As discussed above, the 2007/8 financial crisis had severe economic consequences in Ireland and expenditure cuts were prominent during the FiannaFail led Coalition (2008-2011). However, the Fine Gael-led Coalitions (2011-2016; 2016-2020) then increased investment and extended reforms in children's services. The wide-ranging and damning Report of the Commission to Inquire into Child Abuse (commonly known as the Ryan Report) (Ryan Report Monitoring Group, 2014) provided an important impetus. To better safeguard child and family welfare, it demanded 'more community-based social services', 'lower social work caseloads', 'greater managerial accountability for standards', 'increased funding', 'audits of service provision and service quality' and 'better implementation of statutory guidance' (Ibid, 2014). As noted above, with reference to the EU's Investing in Children strategy, these Coalitions also pledged to 'intensely focus' on early childhood and early intervention investments (Fine Gael Party, 2016).

From 2011, the Department of Children and Youth Affairs (DYCA) was established with extended Ministerial roles to develop and coordinate government policies for children, youth and families. With child welfare concerns high on the agenda, in 2014 the Child and Family Agency (TUSLA) was introduced replacing the FSA. The new agency sought to 'support and promote the development, welfare and protection 
of children and effective functioning of families' (www.tusla.ie). Child protection services, FSA programmes, early intervention programmes, school support services and domestic violence prevention services were brought under TUSLA's governance and delivery structures; and developed informed by strengths-based practice, jointup working and evidence-based practice guidelines. In addition, the DYCA developed its Parenting Support Strategy (Gillen et al, 2013) and Policy Statement on Parenting and Family Support (DCYA, 2015) promoting positive parenting initiatives. These included public awareness campaigns and the Parenting24seven website. An ethos of family support, positive parenting, joint-up working and evidence-informed practice had been promoted via the 'National Service Delivery Framework' (NSDF) and Child and Family Support Networks (CFSNs). A new practice model was introduced (the Meithal model) based on collaborative practice, comprehensive needs assessments and integrated service plans.

These reforms were advanced under the Better Outcomes, Brighter Futures: National Policy Framework for Children and Young People 2014-2020 (DYCA, 2014) which sought to promote 'the rights of all children and young people' and 'support them to realise their maximum potential' (DYCA, 2014, p.4). Echoing the English Every Child Matters reforms, this Framework sought improved outcomes for children and youth in terms of: (1) being active and healthy; (2) achieving full potential in all areas of learning and development; (3) being safe and protected from harm; (4) having economic security and opportunity; and (5) being connected, respected and contributing to their world. 'Supporting Parents' alongside 'early intervention', 'quality services' and 'inter-agency collaboration' were four of six 'cross-cutting themes' and 'transitional goals' (DYCA, 2014, p.25-37). There were further investments in provision to extend and improve 'universal access to good-quality parenting advice and programmes' and 'targeted, evidence-based supports to those parents with greatest needs' (DYCA, 2014).

These have been comprehensive reforms in the Irish context. Major independent evaluations have charted valued and beneficial impacts for parents and children, particularly among developments in community-based services, early intervention schemes, positive parenting support, multi-agency service models, and cross-sector collaboration (Cassidy et al, 2016; Malone and Canavan, 2018). Similar to the English reforms under Labour, there is much evidence of enhanced capacity and coordination across services. In contrast to the English case, these reforms agendas have been retained and extended post-2010. However, the recent Better Outcomes, Brighter Futures and TUSLA reforms remain in the early years of development. Further, there is evidence of ongoing implementation constraints and enduring challenges for cross-sector collaborations in some areas (as between TUSLA and healthcare sectors; statutory and voluntary sectors); and enduring gaps in services such as in rural areas and for higher need families (Malone and Canavan, 2018). Added to these implementation concerns, the professionalisation of the family support workforce and gendered nature of parental roles and needs remain more 
muted issues (Canavan et al, 2016). Further, under conditions of austerity and recession, poverty rates have risen in Ireland in the last decade and referrals to TUSLA child welfare services have increased. Child welfare teams have reported significant problems with service capacity and lost opportunities for preventative practice (Malone and Canavan, 2018).

\section{Service-based reforms in Spain}

As in the cases of England and Ireland, Spain has introduced substantial national 'system-wide' changes and frontline service innovations in the broad area of family support services. Informed by several principals outlined in the EU and COE recommendations discussed above, these reforms have likewise emphasised early intervention, positive parenting, community social services, collaborative practice and evidence-based initiatives. The trajectory of reform, however, differs somewhat from England and Ireland. The Zapatero administration (2004-2011) heralded increased investments and major reforms but these stalled in several respects, and even reversed in some, under the Rajoy administration (2011-2018) and under conditions of austerity. The Sanchez-led coalition (2018 to present), though, has promoted progressive national reforms albeit under challenging economic conditions, returning to greater alignment with EU social investment policies. Further features of the Spanish case are the significance of regional government initiatives and challenges posed by central-regional governance.

Family service reforms in Spain in recent decades built on earlier developments moving beyond charity-based and institutional social services; and moving from a deficit and targeted perspective on family's needs to a preservation model focused on supporting and strengthening families and communities (Jiménez et al, 2019a). The first National Comprehensive Family Support Plan was agreed by the Spanish government in 2001 and implemented over three years. It was a comprehensive strategy to promote a coherent approach across national and regional governments, promoting the family 'as a social asset' and a common national policy approach. Alongside developments in tax measures, social benefits, work - family reconciliation policies, this Plan promoted developments in family support and family mediation services, particularly for families in vulnerable situations. The Zapatero Government then adopted more comprehensive children's rights and social investment orientations which were reflected in the launch of the first National Plan for Childhood and Adolescence (2006-2010) in Spain. This Plan took forwards several recommendations made to Spain in 2002 by the UN committee for children's rights. Measures adopted included further developments in the areas of supports, services and programmes for children and adolescents from families at psycho-social risk.

These Plans have in recent years been updated and expanded. The second 
National Plan for Childhood and Adolescence (2013-2016) sought to promote child and adolescent development, well-being and rights. It sought to further advance the promotion of policies that support families in the exercise of their caretaking responsibilities, education and the full development of children, as well as to facilitate work-family reconciliation, with particular regard to child poverty, gender equality and gender-based violence situations. The second Comprehensive Family Support Plan (2015-2017) sought to develop more comprehensive and coherent economic and social supports for children and families. Service-based developments were orientated towards achieving four national goals: support for motherhood, promoting positive parenting, support for families with special needs and enhanced service coordination and evaluations. Additional national plans addressing social exclusion, domestic violence, social equality and health promotion were also funded and these developed further prevention initiatives, community social services and family healthcare. Further, as part of these plans positive parenting policies have become a priority strategy in family support at the national and regional levels. Aligned with this strategy, a remarkable initiative has been the inclusion of family education and positive parenting programs in the call for subsidy applications funded by the $0.7 \%$ of the income taxes that is devoted to social initiatives provided by the voluntary and charity sector (Ochaita et al, 2018).

As Arranz and Rodrigo (2018, p.1505) emphasised the situation regarding the implementation of positive parenting policies in Spain is very positive, and the field is currently experiencing a period of significant expansion'. These researchers categorised service developments into three types: evidence-based groups parenting programmes which aim to increase parental knowledge of child welfare and development, provide parenting skills training and improve family relationships. These programmes were often delivered by voluntary sector agencies and were reported to be diversifying in their range and target groups beyond parents with young children to, for example, addressing parenting issues for those raising adolescents (Arranz and Rodrigo, 2018). A second category of provision consisted of targeted and tailored support and casework for children and families at risk. These services have also entailed improved cross-sector collaboration between health, education, youth and social services. A third category included the expansion of web-based parenting support and resources; which also included practitioner-orientated resources such as the 'positive families website' (Ibid). The latter provides training, materials and online tools for practitioners. It facilitates knowledge exchange and peer reviews about good practice. In addition, the Best Practice Guide for Positive Parenting (Rodrigo et al., 2015) has been developed for professionals, services' managers and policy-makers informed by research reviews and service standards.

These initiatives highlight the significance of evidence-based policy and practice developments. Decision-makers are increasingly selecting programmes supported by extensive research evidence, and there is increasing use of evidence- 
based programmes (Rodrigo et al, 2016). These include programmes orientated toward early intervention and welfare promotion with manualised approaches and explicit theories of change informed by psycho-educational and community development models (Ibid). Evidence-based developments also encompass therapeutic approaches, such as the adoption of Multisystemic Therapy and other systemic approaches developed by Spanish therapists. An example of a positively evaluated service includes developments in the 'therapeutic alliance' approach (Escudero et al., 2008). However, there are widespread issues inhibiting the adoption of evidence-based programmes, such as their specific remit and target groups; securing resources for training, delivery and evaluation; and professional awareness (Rodrigo et al, 2016). Advocates and researchers have called for more sustainable funding for evidence-based family support programs and greater promotion of their application to preventative family support (Rodrigo et al, 2016). Within regional-level developments, an increasing role for state-university partnerships has developed which is providing an effective strategy for promoting an evidence-based ethos and approach among frontline services and practitioners (Jiménez et al, 2019a).

Overall, there have been significant advances in the conceptualisation, delivery and evaluation of family support services in Spain. Short-comings and challenges remain, however, in realising the vision of comprehensive and coordinated services provided to meet needs, promote welfare and as entitlements. The recently approved child protection Law, however, seeks to enhance child and family entitlements, recognising the right of families with children to psycho-social assessments and support plans (Law 26/2015). Further, while children's rights and family empowerments approaches have gained ground, there needs to be wider adoption of strengths-based and collaborative approaches to supporting children and families as well as more extensive consultation with children and families' in processes of service planning and policy decision-making (Jiménez et al, 2019b). More widespread coordination and cooperation between sectors, territories, and agencies is also needed; and substantial differences remain the development of regional family support policies and plans as well as the spending commitments and capacities of regional governments (Hidalgo et al, 2018). Moreover, the existence and collation of national-level information and data about family support services across regions and at the national-level needs improvement (Pérez-Caramés, 2014). The family support workforce, which is highly inter-disciplinary and intersectoral nature, would also benefit from professional development, training and qualifications upgrades (Jiménez et al, 2019a). These require more extensive and sustained social investment. 


\section{Conclusion}

Within the comparative studies literature, there are few cross-national reviews of service-based family support reforms among European welfare states. This article adopted this approach and examined family support contexts and reforms in the UK, Ireland and Spain. It charted developments in, and changes to, portfolios of public support and social services for children, parents and families in recent decades. It located these within the broader context of prominent European policy frameworks and changing national policy contexts. When considering national approaches to, and developments in, family support services significant similarities and differences emerged. These included similarities in broad policy goals, systemic initiatives and provision innovations. These in turn reflected the influences of common policy ideas and networks. There were significant differences, however, in the specific scope, timing and longevity of national reform strategies and initiatives - reflecting the primary significance of national policy actors, priorities, networks and contexts. All three countries also faced common challenges (securing sustainable family support advancements; improving coordination between central-regional-local governments) and exhibited common short-comings (limited social rights to family support services; enduring gender inequalities in family roles) - although to varying degrees and in varying ways. In respect of the latter aspects of difference, one critical issue has been divergent policy trajectories under conditions of austerity.

The comparison of national reforms provided cross-national insights that warrant further comparative and empirical examination. For example, across all three countries, there is significant research evidence that advancements in communitybased and multi-dimensional children's and family centres were valued by parents, improved service accessibility and responsiveness, and promoted improvements in child, parental and community outcomes. Further, improved coordination and collaboration between service-sectors and professional roles were highly significant for children and families in need. Country-specific innovations that warrant further examination included the development of generic, community-based family support practitioner roles in England (e.g. PSAs in schools); the wide-ranging parenting support stakeholder networks and developments in Spain; and the holistic, intersectoral and multi-agency provision and practice frameworks developed in Ireland. Conversely, the political dimensions of social investments and national reforms in family support highlights the importance of wide-ranging dialogue and collaboration between researchers, advocates, stakeholders and policy-makers involved in the sector. 


\section{References}

Adema, W. (2014) Greater gender equality: What role for family policy? Paris: OECD

Arranz, E. and Rodrigo, M.J. (2018) Positive parenting in Spain: introduction to the special issue. Early Child Development and Care, 188, 11, 1503-1513

Boddy, J., Statham, J., Smith, M., Ghate, D., Wigfall, V., Hauari, H., Canali, C., Danielsen, I., Flett, M., Garbers, S. and Milova, H. (2009) International perspectives on parenting support: Non-English language sources. Research Report DCSF RR114. London: Institute for Education [Accessed 20 June 2019 at https://core.ac.uk/download/pdf/8768799.pdf]

Bonoli, G. (2013) The Origins of Active Social Policy: Labour market and childcare policies in a comparative perspective. Oxford: Oxford University Press

Cabinet Office. (2007) Think family: analysis and themes from the Families at risk review. London: Cabinet Office

Canavan, J., Pinkerton, J. and Dolan, P. (2016) Understanding family support: Policy, practice and theory. London: Jessica Kingsley

Cassidy, A., Devaney, C., McGregor, C. and Landy, F. (2016) Interfacing informal and formal help systems: Historical pathways to the Meitheal model, Administration, 64,2, 137-155

Chief Secretary to the Treasury. (2003) Every child matters. Cm 5860. London: Stationary Office

Churchill, H. (2011) Parental rights and responsibilities: Analysing social policy and lived experiences. Bristol: The Policy Press

Commission on the Family (1998) Strengthening Families for Life. Final Report of the Commission on the Family to the Minister for Social Community and Family Affairs. Dublin: Stationary Office [Accessed 18 July 2019 at https://www.lenus.ie/handle/10147/45565]

Conservative Party. (2010) Invitation to Join the Government of Britain. Conservative Party, London

Council of Europe (COE) (2006) Recommendation Rec (2006)19 of the Committee of Ministers to Member States on Policy to Support Positive Parenting. Strasbourg: Council of Europe Publishing [Accessed 18 July 2019 at https://search.coe.int/cm/Pages/result_details. aspx?ObjectID=09000016805d6dda]

Daly, M. (2015) Part 1: Prevailing policy and provision: Analytical framework and future work. in M. Daly, R. Bray, Z. Bruckauf, J. Byrne, A. Margaria, N. Pecnik and M. SammsVaughan (Eds.) Family and Parenting Support: Policy and Provision in a Global Context. Florence: Innocenti Insight, UNICEF Office of Research (pp. 8-35)

Daly, M., Bray, R., Bruckauf, R., Byrne, J., Margaria, A., Pecnik, N. and Samms-Vaughan, M. (2015) Family and Parenting Support: Policy and Provision in a Global Context. Florence: Innocenti Insight, UNICEF Office of Research [Accessed 12 June 2019 at https://www. unicef-irc.org/publications/pdf/01\%20family_support_layout_web.pdf]

Daly, M. and Clavero, S. (2002) Contemporary family policy: A comparative review of Ireland, France, Germany, Sweden and the UK. Dublin: Department of Social and Family Affairs

Daly, M. and Yeates, N. (2003) Common origins, different paths: adaption and change in social security in Britain and Ireland, Policy and Politics, 31,1,85-97 
Day, L., Bryson, C., White, C., Purdon, S., Bewley, H., Sala, L.K. and Portes, J. (2016). National Evaluation of the Troubled Families Programme. Final Synthesis Report. London: DCLG

Department of Children and Youth Affairs. (DCYA) (2014) Better Outcomes, Brighter Futures: The national policy framework for children and young people 2014-2020. Dublin: Government Publications [Accessed 12 June 2019 at https://www.gov.ie/en/publication/63alff-reportof-the-national-policy-framework-for-children-young-people-20/]

DCYA. (2015) High Level Policy Statement on Supporting Parents and Families (Parenting and Family Support). Dublin: Government Publications [Accessed 12 July 2019 at https:// assets.gov.ie/37254/771e0d95117b4b9096e902a2697a338d.pdf]

Del Valle, J.F., Canali, C., Bravo, A. and Vecchiato, T. (2013) Child protection in Italy and Spain: Influence of the family supported society. Psychosocial Intervention, 22, 3, 227-237

Devaney, C., Canavan, J., Fergal., L. and Aisling, G. (2013) What works in family support? Dublin: Health Service Executive (HSE) [Accessed on 10 October 2019 at https:// www.lenus.ie/bitstream/handle/10147/316734/CFAWhatWorksinFamilySupport. pdf?sequence=1\&isAllowed=y]

Department for Children, Schools and Families (DCSF). (2007) The children's plan: Building brighter futures. Cm 7280. London: DfES

DfES, (2006) Parenting support guidance for local authorities in England. London: DfES

Department for Health and Children (DHC). (1999) Guidelines for the protection and welfare of children. Dublin: DHC

Dukelow, F. and Considine, M. (2017) Irish social policy: a critical introduction, 2nd edition, Bristol: Policy Press

Eisenstadt, N. and Oppenheim, C. (2020) Parents, poverty and the state. Bristol: The Policy Press

Elizalde-San Miguel, B., Día, V. and Sanz, M.T. (2016) The impact of family-friendly practices on work-family balance in Spain. Applied Research Quality Life, 11, 983-1007

Elizalde-San Miguel, B., Día, V. and Sanz, M. T. (2019) Family Policy Index: A tool for policy makers to increase the effectiveness of family policies. Social Indicators Research, $142,387-349$

Escudero, V., Friedlander, M.L., Varela, N. and Abascal, A. (2008) Observing the therapeutic alliance in family therapy: Associations with participants' perceptions and therapeutic outcomes. Journal of Family Therapy, 30, 2, 194-204

Esping-Andersen, G. (1999) Social foundations of post-industrial economies. Oxford: Oxford University Press

European Commission (EC) (2013) European Commission Recommendation of 20 February 2013: Investing in Children: Breaking the Cycle of Disadvantage. Brussels: European Commission [Accessed 20 June 2019 at https://eur-lex.europa.eu/LexUriServ/LexUriServ.do?uri=OJ: L:2013:059:0005:0016:EN:PDF ]

Fahey, T. and Nixon, E. (2014) 'Family Policy in Ireland'. in M. Robila (Ed.) The Handbook of Family Policies across the Globe. New York: Springer (pp. 125-136)

Featherstone, B., Gupta, A., Morris, K. and White, S. (2018) Protecting children: a social model. Bristol: The Policy Press 
Ferrera, M. (2010) The south European countries. in F. Castles, S. Leibfried, J. Lewis, H. Obinger and C. Pierson (Eds.) The Oxford handbook of the welfare state. Oxford: Oxford University Press (pp. 616-628)

Fine Gael Party. (2011) Fine Gael manifesto: Let's get Ireland working. Dublin: Fine Gael Party Fine Gael Party. (2016) Fine Gael general election manifesto 2016: Let's keep the recovery going. Dublin: Fine Gael Party

Frost N., Abbott, S. and Race, T. (2015) Family support: Prevention, early intervention and early help. Cambridge: Policy Press

Gilbert, N. (2012) A comparative study of child welfare systems: Abstract orientations and concrete results. Children and Youth Services Review, 34, 3, 532-536

Gillen, A., Tuohy, O., Morrissey, M., Gaynor, J., Canavan, J., Devaney, C., Landy, F. and Coen, L. (2013) Investing in Families: Supporting Parents to Improve Outcomes for Children: Dublin: Child and Family Agency TULSA [Accessed 3 October 2019 at https://www.tusla. ie/uploads/content/Family_Support_CFA_Parenting_Support_Strategy.pdf]

Hanafin, S., Brooks, A-M., Roche, G. and Meaney, B. (2012) Advancing understandings of child well-being through the strategic development of a national children's research programme, Childhood Indicators Research, 5, 567-586

Hemerijck, A. (2018) 'Social investment as a policy paradigm'. Journal of European Public Policy, 25, 6),810-827. doi:https://doi.org/10.1080/13501763.2017.1401111

Hidalgo, V., Pérez-Padilla, J., Sánchez, J., Ayala-Nunes, L., Maya, J., Grimaldi, V. and Menéndez, S. (2018) An analysis of different resources and programmes supporting at-risk families in Spain. Early Child Development and Care, 188, 11, 1476-8275

Home Office. (2006) Supporting families: a consultation paper. London: Stationary Office

Jiménez, L., Antolín-Suárez, L., Lorence, B. and Hidalgo, V. (2019a) Family education and support for families at psychosocial risk in Europe: evidence from a survey of international experts. Health \& Social Care in the Community, 27, 2, 449-458

Jiménez, L., Astiz, D., Hidalgo, V. and Contín, M. (2019b) Ensuring respect for at-risk children's rights. Lessons learned from home- and group-based family education programs. in L. Moran and J. Canavan (Eds.) Realising children's rights through supporting parents. Galway: UNESCO Child and Family Research Centre [Accessed on 22 February 2020 at https://bilson.org.uk/wp_new/wp-content/uploads/2020/02/Building-aneconomic-case-published.pdf]

Kelly, E., Lee, T., Sibieta, L. and Waters, T. (2018) Public spending on children in England: 2000 to 2020, London: Institute for Fiscal Studies

León, M. and Pavolini, E. (2014) Social investment or back to familism: The impact of the economic crisis on family and care policies in Italy and Spain. South European Society and Politics, 9, 3, 353-369

Lewis, J. (1992) Gender and the development of welfare regimes. Journal of European Social Policy, 2,3, 159-73

Lindsay, G., Davis, H., Strand, S., Cullen, M.A., Band, S., Cullen, S., Davis, L., Hasluck, C., Evans, R. and Stewart-Brown, S. (2009) Parent support adviser pilot evaluation: Final report. DCSF-RR151, London: DSCF 
Lindsay, G., Cullen, M.A., Cullen, S., Totsika, V., Bakopoulou, I., Goodlad, S., Brind, R., Pickering, E., Bryson, C., Purdon, S., Conlon, G. and Mantovani, I. (2014) The Canparent trial evaluation: Final report. London: DfE

Malone, P. and Canavan, J. (2018) Systems Change: Final Evaluation Report on Tusla's Prevention, Partnership and Family Support Programme. Galway: UNESCO Child and Family Research Centre [Accessed on 10 November 2019 at http://www.childandfamilyresearch.ie/ media/unescochildandfamilyresearchcentre/dmpfinalreports/Systems-Change-FinalEvaluation-Report.pdf]

Melhuish, E., Belsky, J. and Leyland, A. (2009) The impact of Sure Start local programmes on three year olds and their families. NESS/2008/FR/027, London: Stationary Office

Millar, M. (2003) Institutionalism 'old' and 'new'. in M, Adshead. and M. Millar (Eds.) Public administration and public policy in Ireland: theory and methods. London: Routledge. (pp.129-46)

Millar, M. and Crosse, R. (2018) Lone Parent Activation in Ireland: putting the cart before the horses? Social Policy and Administration, 52, 1, 111-29

Munro, E. (2011) The Munro review of child protection: a child centred system: Final report. Norwich: Stationary Office

Naldini, M. (2004) The family in the Mediterranean welfare states. London: Routledge

National Audit Office (NAO). (2018) Financial Sustainability of Local Authorities. London: NAO [Accessed 20 June 2019 at www.nao.org.uk/wp-content/uploads/2018/03/Financialsustainabilty-of-local-authorites-2018-Summary.pdf.]

National Economic and Social Council (NESC). (2005) The developmental welfare state. Dublin: NESC

OECD. (2009) Doing better for children. Paris: OECD

OECD. (2011) Doing better for families. Paris: OECD

Ochaita, E., Espinosa, M.A., García-Llorente, I. and Fernández-López, M. (2018) The role of NGOs in the dissemination and implementation of positive parenting in Spain. Early Child Development and Care, 188, 11, 1514-1527

Pérez-Caramés, A. (2014) 'Family Policy in Spain'. in M. Robila (Ed.) The Handbook of Family Policies across the Globe. New York: Springer

Pinkerton, J., Dolan, P. and Canavan, J. (2004) Family support in Ireland: Definition and strategic intent. Dublin: DHC

Rochford, S., Doherty, N. and Owens, S. (2014) Prevention and Early Intervention in Children and Young People's Services: Ten years of Learning. Dublin: Centre for Effective Services [Accessed on 6 January 2019 at https://www.drugsandalcohol.ie/24411/1/CES_PEII_10_ Years_of_Learning_Report.pdf]

Rodrigo, M.J. (2010) Promoting positive parenting in Europe: New Challenges for the European Society for Developmental Psychology. European Journal of Developmental Psychology, 7,2, 281-294

Rodrigo, M.J., Amorós, P., Arranz, E., Hidalgo, V., Máiquez M.L., Martín, J.C., Amaya, R. and Ochaita, E. (2015) Best practice guide for positive parenting. A resource for practitioners working with families. Madrid: FEMP [Accessed on 12 March 2019 at https://www.mscbs. 
gob.es/ssi/familiasInfancia/ayudas/docs2013-14/GuiadeBuenasPracticas2015.pdf]

Rodrigo, M.J., Byrne, S. and Álvarez, M. (2016) Interventions to promote positive parenting in Spain. in M. Israelashvili and J.L. Romano (Eds.) Cambridge handbook of international prevention science. Cambridge: Cambridge University Press (pp. 929-956)

Ruggiero, R. (2013) Public policies supporting parenting parenthood: New policy perspectives. The proceedings of the ChildONEurope seminar on out-of-home children. Florence: Instituto degli Innocenti [Accessed on 3 March 2019 at http://www.childoneurope.org/issues/ publications/COEseries8-Positiveparenthood.pdf]

Ryan Report Monitoring Group. (2014) Ryan report implementation plan. [Accessed 1 March 2020 at https://www.gov.ie/pdf/?file=https://assets.gov.ie/25855/ be8de857a5c24c2d8b303b49eal087bb.pdf\#page=1 ]

Social Exclusion Taskforce (SETF). (2006) Reaching out: social exclusion action plan. London: Stationary Office

Tunstill, J., Tarr, S. and Thoburn, J. (2008). Family Support Review: Cross sector scoping study of family support workers in the children's workforce. London: Synergy Research \& Consulting Ltd

UNCRC (1989) Resolution 44/25 Convention on the Rights of the Child (20 November 1989) [Accessed on 6 January 2019 at https://downloads.unicef.org.uk/wp-content/ uploads/2010/05/UNCRC_united_nations_convention_on_the_rights_of_the_child. pdf?_ga=2.163474620.1442013838.1586294265-1731106399.1586294265] 